\title{
Status Report: Stress Corrosion Cracking of Ni-Base and Ti Alloys
}

\author{
Ajit K. Roy
}

December 1, 1998

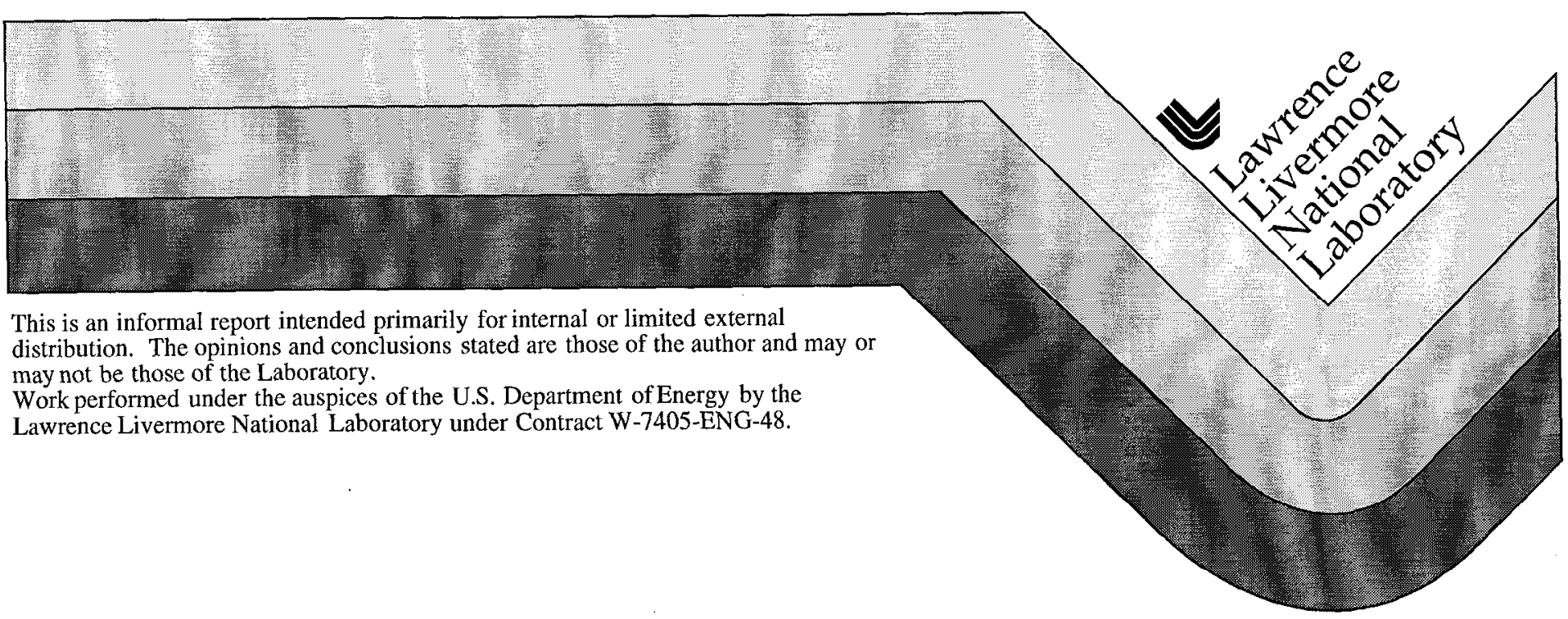





\section{DISCLAIMER}

This document was prepared as an account of work sponsored by an agency of the United States Government. Neither the United States Government nor the University of California nor any of their employees, makes any warranty, express or implied, or assumes any legal liability or responsibility for the accuracy, completeness, or usefulness of any information, apparatus, product, or process disclosed, or represents that its use would not infringe privately owned rights. Reference herein to any specific commercial product, process, or service by trade name, trademark, manufacturer, or otherwise, does not necessarily constitute or imply its endorsement, recommendation, or favoring by the United States Government or the University of California. The views and opinions of authors expressed herein do not necessarily state or reflect those of the United States Government or the University of California, and shall not be used for advertising or product endorsement purposes.

This report has been reproduced directly from the best available copy.

Available to DOE and DOE contractors from the Office of Scientific and Technical Information P.O. Box 62, Oak Ridge, TN 37831

Prices available from (423) 576-8401

Available to the public from the National Technical Information Service

U.S. Department of Commerce

5285 Port Royal Rd.,

Springfield, VA 22161 



\section{Civilian Radioactive Waste Management System Management \& Operating Contractor}

Status Report: Stress Corrosion Cracking of Ni-Base and Ti Alloys

Draft B

December 1998

Prepared for:

TRW Environmental Safety Systems Inc. 1261 Town Center Drive

Las Vegas, Nevada 89134-6352

Prepared by:

Lawrence Livermore National Laboratory

P.O. Box 808

Livermore, California 94551-0808

Under Memorandum Purchase Order HD2979KR5X 

Civilian Radioactive Waste Management System

Management \& Operating Contractor

Status Report: Stress Corrosion Cracking of Ni-Base and Ti Alloys

Draft B

December 1998

Prepared by:

Name

Date

Name

Date

Approved by:

Name

Date

Name

Date 



\section{Status Report: \\ Stress Corrosion Cracking of Ni-Base and Ti Alloys}

WP267M4

by

Ajit K. Roy

December 1998

Lawrence Livermore National Laboratory

Livermore, California 


\section{DISCLAIMER}

This document was prepared as an account of work sponsored by an agency of the United States Government. Neither the United States Government nor the University of California nor any of their employees, makes any warranty, express or implied, or assumes any legal liability or responsibility for the accuracy, completeness, or usefulness of any information, apparatus, product, or process disclosed, or represents that its use would not infringe privately owned rights. Reference herein to any specific commercial product, process, or service by trade name, trademark, manufacturer, or otherwise, does not necessarily constitute or imply its endorsement, recommendation, or favoring by the United States Government or the University of California. The views and opinions of authors expressed herein do not necessarily state or reflect those of the United States Government or the University of California, and shall not be used for advertising or product endorsement purposes.

This report has been reproduced directly from the best available copy.

Available to DOE and DOE contractors from the Office of Scientific and Technical Information

P.O. Box 62, Oak Ridge, TN 37831

Prices available from (615) 576-8401, FTS 626-8401

Available to the public from the National Technical Information Service

U.S. Department of Commerce 5285 Port Royal Rd. Springfield, VA 22161

This is an informal report intended primarily for internal distribution.

The opinions and conclusions stated are those of the author and may or may not be those of the Laboratory.

Work performed under the auspices of the Department of Energy by the

Lawrence Livermore National Laboratory under Contract W-7405-Eng-48. 


\section{Contents}

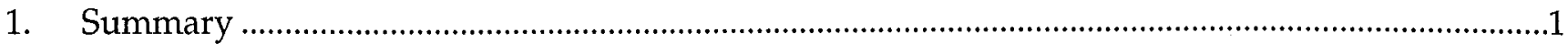




\section{Abbreviations and Acronyms}

$\begin{array}{ll}\text { DCB } & \text { double-cantilever beam } \\ \text { SCC } & \text { stress corrosion cracking } \\ \text { SEM } & \text { scanning electron microscopy } \\ \text { SSR } & \text { slow strain rate } \\ \text { TTF } & \text { total time to failure }\end{array}$




\section{Summary}

Susceptibility to stress corrosion cracking (SCC) of two candidate alloys for the inner container of the multibarrier nuclear waste package was evaluated by using wedge-loaded, precracked, double-cantilever-beam (DCB) specimens and the slow-strain-rate (SSR) test technique. Materials tested included Alloy $\mathrm{C}-22$ and Ti Gr-12. A deaerated $90^{\circ} \mathrm{C}$ acidic brine $(\mathrm{pH}$ $\approx 2.70$ ) containing 5 weight percent $\mathrm{NaCl}$ was used as the test environment. Both DCB and SSR tensile specimens were machined from mill-annealed plate materials. No additional thermal treatments were given to these specimens prior to their being exposed to the test solution. The DCB testing was performed for periods ranging from one through eight months. The initial and final stress intensity factor $\left(\mathrm{K}_{\mathrm{I}}\right.$ and $\left.\mathrm{K}_{\mathrm{f}}\right)$ values were calculated using a standard fracture-mechanics equation. Fractographic evaluation of the broken DCB specimens was performed by using scanning electron microscopy (SEM) to analyze the characteristics of failures.

During SSR testing, a strain rate of $3.3 \times 10^{-6} \mathrm{sec}^{-1}$ was used. Before being tested in the acidic brine, tensile specimens of each alloy were pulled in the test chamber in the dry condition at room temperature. Then, while in the test solution, the specimens were strained under different controlled electrochemical potentials. The controlled potentials $\left(\mathrm{E}_{\text {cont }}\right)$ were selected based on the corrosion potential measured in the test solution before the specimens were strained. The load versus displacement curve for each specimen was recorded. Ductility parameters such as the percent elongation $(\% \mathrm{El})$, the percent reduction in area $(\% \mathrm{RA})$, the true fracture stress $\left(\sigma_{\mathrm{f}}\right)$, and the total time-to-failure (TTF) were determined. Finally, metallographic examination was performed to evaluate the primary fracture and the secondary cracking, if any, along the gage section of the broken tensile specimen.

Results of DCB testing indicate that compared to Ti Gr-12, Alloy C-22 exhibited higher cracking susceptibility in terms of average crack growth. Further, cracking in both alloys might have been arrested after exposures of four to five months because no significant crack extensions were observed beyond this test duration. Fractographic evaluation by SEM revealed three distinct regions showing the characteristics of fatigue precrack (striations), SCC (transgranular brittle failure), and fast fracture (dimples).

The results of SSR testing indicate that the ductility of $\mathrm{Ti} \mathrm{Gr}-12$ in terms of $\sigma_{\mathfrak{f}}$ and \%RA was gradually reduced with more cathodic (negative) $\mathrm{E}_{\text {cont }}$ values. The secondary cracking along the gage section of all potentiostatically polarized $\mathrm{Ti} \mathrm{Gr}-12$ specimens was transgranular, confirming observations by other investigators. The primary fracture face showed the characteristics of a brittle failure. With regard to SCC behavior, Alloy C-22 was immune to cracking under environmental conditions used in a limited number of experiments performed so far. 
